\title{
Denitrification by Strains of Neisseria, Kingella, and Chromobacterium
}

\author{
MICHAEL A. GRANT AND W. J. PAYNE \\ Department of Microbiology, University of Georgia, Athens, Georgia 30602
}

\begin{abstract}
The information in the existing literature concerning the denitrifying capacities of certain species of Kingella, Chromobacterium, and Neisseria is ambiguous. Therefore, we used gas chromatography to obtain a better understanding of the capacities of strains of several species in these genera for dissimilatory nitrate and nitrite reduction under anoxic conditions. A strain of Kingella denitrificans used both nitrate and nitrite as electron acceptors for denitrification, as did strains of "Chromobacterium lividum" and Chromobacterium violaceum. In contrast, strains of four of the Neisseria species tested denitrified at the expense of nitrite, but strains of three species did not reduce nitrite. Only a strain of Neisseria mucosa used nitrate as an electron acceptor. Therefore, all strains tested were capable of denitrification. Where lapses occurred, it was the capacity for nitrate reduction that was missing, as in certain species of Alcaligenes. The lack of the ability to reduce nitrous oxide that is found in some Pseudomonas species was not observed in this study.
\end{abstract}

Information concerning the nitrate- and nitrite-reducing properties of species of Kingella, Chromobacterium, and Neisseria is limited to data obtained by standard nitrate and nitrite broth tests $(2,7,10,11,13)$. The results of such tests do not necessarily reveal whether a nitratereducing bacterium uses assimilatory or dissimilatory reduction or nitrate fermentation $(4,5)$. Dissimilatory reduction of nitrate can produce nitrite and stop or can produce ammonia and stop, or it can go on in denitrifiers and release nitric oxide and nitrous oxide as intermediates and dinitrogen as the final product (6). Assimilatory reduction of nitrate and nitrate fermentation produces nitrite that can then be further reduced to ammonia.

The taxonomy of bacteria would be served if the capabilities of all nitrate and nitrite reducers were determined more precisely. To that end, we examined strains of Kingella denitrificans, "Chromobacterium lividum" (not on the Approved Lists of Bacterial Names [8]), Chromobacterium violaceum, Neisseria mucosa, Neisseria sicca, Neisseria flavescens, and Neisseria subflava to determine whether they are capable of denitrification, as suspected.

\section{MATERIALS AND METHODS}

Bacterial strains. C. violaceum ATCC 12472 and "C. lividum" ATCC 12473 were obtained from the American Type Culture Collection, Rockville, Md. A culture of $K$. denitrificans was kindly provided by Richard George, and the N. mucosa, N. sicca, N. subflava, and $N$. flavescens strains were obtained from Douglas Kellog, Centers for Disease Control, Atlanta,
Ga. It should be noted that since the strains which we used are not the type strains of the species, it would be taxonomically improper to extrapolate the results obtained with these strains to the whole species.

Culture conditions. Cultures of the Neisseria and Kingella strains were grown at $37^{\circ} \mathrm{C}$ in tryptic soy broth (Difco Laboratories, Detroit, Mich.) containing $1.0 \%$ defibrinated sheep blood and either $0.1 \%$ (wt/vol) $\mathrm{NaNO}_{3}$ or $0.01 \%$ (wt/vol) $\mathrm{NaNO}_{2}$. Cultures of the Chromobacterium strains were incubated at $22^{\circ} \mathrm{C}$ in tryptic soy broth containing $0.1 \%$ yeast extract and either $0.1 \% \mathrm{NaNO}_{3}$ or $0.01 \% \mathrm{NaNO}_{2}$.

The media were dispensed in $50-\mathrm{ml}$ portions into $120-\mathrm{ml}$ serum bottles and sterilized. Immediately after autoclaving, the containers were sealed with rubber serum bottle stoppers. After the media cooled to approximately $70^{\circ} \mathrm{C}$, blood was injected aseptically into the appropriate media, thus rupturing the blood cells. Needles were inserted through the stoppers, and all of the test flasks were flushed aseptically for approximately $5 \mathrm{~min}$ with either helium or argon (made oxygen-free by passage over hot copper filings). At periodic intervals, samples were withdrawn from the headspace of each culture with a Hamilton gas-tight syringe or a disposable tuberculin syringe. Samples of medium were also withdrawn periodically and diluted into a Petroff-Hausser counting chamber for direct cell counts with a phase-contrast microscope.

Gas chromatography. Gas samples were analyzed with either a Carle III analytical gas chromatograph or a Perkin-Elmer model 900 gas chromatograph. The Carle instrument was equipped with a Poropak $\mathbf{Q}$ column (approximately 304 by $0.32 \mathrm{~cm}$ ), which was operated at $70^{\circ} \mathrm{C}$. This instrument was also equipped with a thermal conductivity microdetector, and helium was used as the carrier gas (flow rate, approximately $31 \mathrm{ml} / \mathrm{min}$ ). The Perkin-Elmer model 900 chromatograph was equipped with a Poropak Q column (ap- 
proximately 183 by $0.34 \mathrm{~cm}$ ), which was operated at ambient temperature. This apparatus contained a thermal conductivity detector which was operated at $100^{\circ} \mathrm{C}$ and at a current setting of $15 \mathrm{~mA}$. Argon was used as the carrier gas (flow rate, approximately 40 $\mathrm{ml} / \mathrm{min}$ ).

\section{RESULTS AND DISCUSSION}

The strain of $K$. denitrificans examined was clearly capable of denitrifying metabolism when it was grown with nitrate as the electron acceptor (Table 1). We sought qualitative rather than quantitative indications of gas release. Thus, we made our final observations before complete conversion of nitrate or nitrite nitrogen. The quantities of dinitrogen being released were still increasing when our observations were concluded. Nitrous oxide, which accumulated transiently during the dissimilatory process, was observed first at $48 \mathrm{~h}$ and appeared maximally at $72 \mathrm{~h}$. Smaller quantities of typical denitrifying products accumulated when nitrite was the electron acceptor. Dinitrogen production with nitrite was only one-half that observed with nitrate, and a small quantity of nitrous oxide was de-

TABLE 1. Gas production by a K. denitrificans strain with nitrate or nitrite as electron acceptor

\begin{tabular}{|c|c|c|c|c|c|c|}
\hline \multirow{3}{*}{$\begin{array}{l}\text { Duration } \\
\text { of incuba- } \\
\text { tion (h) }\end{array}$} & \multicolumn{6}{|c|}{$\begin{array}{l}\text { Amt (nmol } / \mathrm{ml} \text { of headspace) of gases produced } \\
\text { by cells grown with: }\end{array}$} \\
\hline & \multicolumn{3}{|c|}{ Nitrate $^{a}$} & \multicolumn{3}{|c|}{ Nitrite $^{b}$} \\
\hline & $\mathrm{CO}_{2}$ & $\mathbf{N}_{2} \mathbf{O}$ & $\mathbf{N}_{2}$ & $\mathrm{CO}_{2}$ & $\mathrm{~N}_{2} \mathrm{O}$ & $\mathrm{N}_{2}$ \\
\hline 0 & 0 & 0 & 0 & 0 & 0 & 0 \\
\hline 12 & 162 & 0 & 20 & 72 & 0 & 46 \\
\hline 24 & 269 & 0 & 162 & 150 & 4 & 111 \\
\hline 48 & 440 & 47 & 699 & 539 & 0 & 1,208 \\
\hline 67 & 4,989 & 833 & 1,758 & 620 & 0 & 2,164 \\
\hline 72 & 5,012 & 1,041 & 1,825 & 648 & 0 & 2,295 \\
\hline 100 & 5,338 & 667 & 2,610 & 851 & 0 & 2,900 \\
\hline
\end{tabular}

${ }^{a}$ Initially, the cultures contained $11.8 \mathrm{mmol}$ of $\mathrm{NO}_{3}{ }^{-}$per $\mathrm{ml}\left(167.9 \mu \mathrm{g}\right.$ of $\mathrm{NO}_{3}{ }^{-}$nitrogen per $\left.\mathrm{ml}\right)$.

${ }^{b}$ Initially, the cultures contained $1.4 \mathrm{mmol}$ of $\mathrm{NO}_{2}{ }^{-}$per $\mathrm{ml}$ (20.46 of $\mu \mathrm{g} \mathrm{NO}_{2}{ }^{-}$nitrogen per $\mathrm{ml}$ ). tected only at $24 \mathrm{~h}$. Nonetheless, nitrite apparently supported true denitrification since dinitrogen concentrations increased steadily and ammonia concentrations decreased from 27 to $20 \mu \mathrm{g}$ of $\mathrm{NH}_{3}$-nitrogen per $\mathrm{ml}$ during the incubation period. Such a result was not unexpected, for certain denitrifying bacteria do not liberate nitrous oxide during normal denitrifying growth (1).

Snell and Lapage (13) reported gas production during growth of $K$. denitrificans on nitrite broth but not during growth on nitrate broth. In our experiments, the production of gas at the expense of nitrate may have been attributable to the nutritionally richer medium which we used or to the lower oxygen tension which was likely to be achieved in our sealed vessels than in the standard tube test.

C. violaceum ATCC 12472 exhibited denitrifying metabolism with either nitrate or nitrite as the electron acceptor (Table 2). As expected, smaller quantities of dinitrogen and carbon dioxide (the two major gaseous metabolic end products) were released from the nitrite-containing medium than from the nitrate-enriched medium. The benefit of oxidative phosphorylation coupled to nitrate reduction was not available when nitrite was the electron acceptor. In addition, a concentration of nitrite only one-tenth the concentration of nitrate is likely to be tolerated by these bacteria, which are sensitive to elevated quantities of nitrite (6) even if they can reduce it.

"C. lividum" ATCC 12473 also exhibited denitrifying metabolism with nitrate or nitrite. Chromobacteria currently are described (12) as organisms that reduce both nitrate and nitrite, sometimes with visible gas production. Our study indicates that total gas production in standard test tubes was probably greater on nitrate-containing media than on nitrite-containing media for both $C$. violaceum and " $C$. lividum." Nitrous oxide should have contributed

TABLE 2. Gas production by chromobacteria grown on media supplemented with nitrate or nitrite

\begin{tabular}{|c|c|c|c|c|c|c|c|c|c|c|c|c|}
\hline \multirow{3}{*}{$\begin{array}{l}\text { Duration of } \\
\text { incubation } \\
\text { (h) }\end{array}$} & \multicolumn{6}{|c|}{$\begin{array}{l}\text { Amt (nmol/ml of headspace) of gases produced by } \\
\text { "C. lividum" ATCC } 12473 \text { grown with: }\end{array}$} & \multicolumn{6}{|c|}{$\begin{array}{l}\text { Amt }(\mathrm{nmol} / \mathrm{ml}) \text { of gases produced by } C . \text { violaceum } \\
\text { ATCC } 12472 \text { grown with: }\end{array}$} \\
\hline & \multicolumn{3}{|c|}{ Nitrate $^{a}$} & \multicolumn{3}{|c|}{ Nitrite $^{b}$} & \multicolumn{3}{|c|}{ Nitrate $^{a}$} & \multicolumn{3}{|c|}{ Nitrite $^{b}$} \\
\hline & $\mathrm{CO}_{2}$ & $\mathrm{~N}_{2} \mathrm{O}$ & $\mathbf{N}_{2}$ & $\mathrm{CO}_{2}$ & $\mathrm{~N}_{2} \mathrm{O}$ & $\mathbf{N}_{2}$ & $\mathrm{CO}_{2}$ & $\mathrm{~N}_{2} \mathrm{O}$ & $\mathbf{N}_{2}$ & $\mathrm{CO}_{2}$ & $\mathrm{~N}_{2} \mathrm{O}$ & $\mathbf{N}_{2}$ \\
\hline 0 & 0 & 0 & 0 & 0 & 0 & 0 & 0 & 0 & 0 & 0 & 0 & 0 \\
\hline 14 & 252 & 60 & 192 & 158 & 152 & 227 & 330 & 12 & 160 & 108 & 0 & 251 \\
\hline 22 & 328 & 51 & 507 & 348 & 277 & 501 & 1,116 & 66 & 1,120 & 201 & 0 & 541 \\
\hline 48 & 519 & 59 & 1,014 & 413 & 312 & 773 & 483 & 1,325 & 1,690 & 413 & 161 & 687 \\
\hline 72 & 1,204 & 73 & 1,332 & 822 & 259 & 924 & 594 & 1,191 & 2,000 & 662 & 572 & 738 \\
\hline
\end{tabular}

${ }^{a}$ Initial quantity as described in Table 1 , footnote $a$.

${ }^{b}$ Initial quantity as described in Table 1 , footnote $b$. 
TABLE 3. Gas production by strains of four species of Neisseria

\begin{tabular}{|c|c|c|c|c|c|c|c|c|c|c|c|c|c|c|c|}
\hline \multirow{4}{*}{$\begin{array}{c}\text { Duration } \\
\text { of incuba- } \\
\text { tion (h) }\end{array}$} & \multicolumn{15}{|c|}{ Amt ( $\mathrm{nmol} / \mathrm{ml}$ of headspace) of gases produced } \\
\hline & \multirow{2}{*}{\multicolumn{3}{|c|}{$\begin{array}{l}N . \text { sicca: } \\
\text { medium }^{a}\end{array}$}} & \multirow{2}{*}{\multicolumn{3}{|c|}{$\begin{array}{l}\text { N. flavescens: nitrite } \\
\text { medium }^{a}\end{array}$}} & \multirow{2}{*}{\multicolumn{3}{|c|}{$\begin{array}{l}\text { N. subflava: nitrite } \\
\text { medium }^{a}\end{array}$}} & \multicolumn{6}{|c|}{ N. $m u \cos a$} \\
\hline & & & & & & & & & & \multicolumn{3}{|c|}{ Nitrite medium ${ }^{a}$} & \multicolumn{3}{|c|}{ Nitrate medium ${ }^{b}$} \\
\hline & $\mathrm{CO}_{2}$ & $\mathrm{~N}_{2} \mathrm{O}$ & $\mathbf{N}_{2}$ & $\mathrm{CO}_{2}$ & $\mathrm{~N}_{2} \mathrm{O}$ & $\mathbf{N}_{2}$ & $\mathrm{CO}_{2}$ & $\mathrm{~N}_{2} \mathrm{O}$ & $\mathrm{N}_{2}$ & $\mathrm{CO}_{2}$ & $\mathrm{~N}_{2} \mathrm{O}$ & $\mathbf{N}_{2}$ & $\mathrm{CO}_{2}$ & $\mathrm{~N}_{2} \mathrm{O}$ & $\mathbf{N}_{2}$ \\
\hline 0 & 0 & 0 & 0 & 0 & 0 & 0 & 0 & 0 & 0 & 0 & 0 & 0 & 0 & 14 & 208 \\
\hline 16 & 158 & 43 & 223 & 56 & 9 & 135 & 55 & 5 & 122 & 1,189 & .97 & 722 & 748 & 11 & 365 \\
\hline 24 & 265 & 17 & 311 & 69 & 38 & 183 & 119 & 4 & 312 & 2,236 & 0 & 1,086 & 1,515 & 0 & 487 \\
\hline 48 & 420 & 0 & 400 & 214 & 166 & 863 & 396 & 0 & 479 & 3,006 & 0 & 1,139 & $\mathbf{4 , 3 5 1}$ & 0 & 1,679 \\
\hline 67 & 437 & 0 & 501 & 500 & 0 & 1,138 & 478 & 0 & 872 & 3,290 & 0 & 1,275 & 5,609 & 0 & 2,342 \\
\hline
\end{tabular}

\footnotetext{
${ }^{a}$ Initial quantity as described in Table 1, footnote $a$.

${ }^{b}$ Initial quantity as described in Table 1 , footnote $b$. The strain of $N$. mucosa was the only Neisseria strain tested that reduced nitrate.
}

only minimally to the final volume of gas, as it accumulates only transiently and is more soluble than dinitrogen in water.

It should be noted that carbon dioxide production may not be due solely to anaerobic respiration in any of the organisms used in this study. All seven strains which we examined are capable of fermentation, and it is not known whether this process is repressed during respiratory reduction of nitrate or nitrite. Fermentation may be responsible, in part, for fluctuating $\mathrm{CO}_{2} / \mathrm{N}_{2}$ ratios and $\mathrm{CO}_{2}$ disappearence (Table 2). Propionibacterium pentosaceum reportedly exhibits different patterns of organic acid release in the presence of nitrate and in its absence, but none of the denitrifying bacteria has been studied extensively with regard to fermentative versus denitrifying metabolism $(3,14)$.

The four Neisseria strains tested used nitrite as the terminal electron acceptor for denitrifying metabolism (Table 3). All of the nitrite which was provided was consumed by each strain within the first $24 \mathrm{~h}$ of incubation. Currently, these four strains are described as nitrite reducers (7). After 3 days, only a very small quantity of nitrous oxide was produced by the strain of $N$. subflava, and the ammonia concentration in the N. subflava cultures increased from 22 to $31.5 \mu \mathrm{g}$ of $\mathrm{NH}_{3}$ nitrogen per $\mathrm{ml}$. The other Neisseria strains did not produce increased concentrations of ammonia. Consequently, even though the strain of $N$. subflava clearly denitrified (as shown by nitrous oxide production and dinitrogen production), assimilatory nitrite reduction or nitrite fermentation may have been competing simultaneously for the electron acceptor. The strain of N. mucosa was the only Neisseria strain which was able to use nitrate as an electron acceptor for denitrification.

Our results show that although nitrous oxide is an indicator of denitrification, it is present only transiently. This observation raises the pos- sibility that a single analysis of evolved gases after incubation of an unknown bacterium for a specified length of time might not reveal this characteristic gas. Alternatively, a procedure such as that described by Tiedje (J. M. Tiedje, in Methods of Soil Analysis, 2nd ed., in press) may be preferred for detecting denitrifying metabolism. This procedure involves incubating the test bacterium in nitrate broth in a sealed, Hungate-type tube closed with a screw cap that exposes a butyl rubber septum. The culture is flushed with inert gas, and $1 \mathrm{ml}$ of acetylene is injected through the septum into the headspace over the liquid medium immediately after inoculation. Acetylene prevents reduction of nitrous oxide to dinitrogen but does not otherwise affect denitrification $(1,9,15)$. Consequently, nitrous oxide accumulates and may be withdrawn and identified by gas chromatography as a certain indicator of denitrification (6).

\section{ACKNOWLEDGMENTS}

We are grateful to Carol Bilbrough for technical assistance.

This study was supported by grant OCE 79-19550 from the National Science Foundation.

\section{REPRINT REQUESTS}

Address reprint requests to: $M$. A. Grant, Department of Microbiology, University of Georgia, Athens, GA 30602.

\section{LITERATURE CITED}

1. Balderston, W. L., B. Sherr, and W. J. Payne. 1976. Blockage by acetylene of nitrous oxide reduction in Pseudomonas perfectomarinus. Appl. Environ. Microbiol. 31:504-508.

2. Cowan, S. T., and K. J. Steel. 1965. Manual for the identification of medical bacteria. Cambridge University Press, Cambridge.

3. De Vries, W., W. M. C. Van Wijck-Kapteyn, and A. H. Stouthamer. 1972. Influence of oxygen on growth, cytochrome synthesis and fermentation pattern in propionic acid bacteria. J. Gen. Microbiol. 71:515-524.

4. Hasan, S. M., and J. B. Hall. 1975. The physiological function of nitrate reduction in Clostridium perfringens. J. Gen. Microbiol. 87:120-128. 
5. Inderlied, C. B., and E. A. Delwiche. 1973. Nitrate reduction and the growth of Veillionella alcalescens. J. Bacteriol. 114:1206-1212.

6. Payne, W. J. 1973. Reduction of nitrogenous oxides by microorganisms. Bacteriol. Rev. 37:409-452.

7. Reyn, A. 1974. Neisseriaceae, p. 427-432. In R. E. Buchanan and N. E. Gibbons (ed.), Bergey's manual of determinative bacteriology, 8th ed. The Williams \& Wilkins Co., Baltimore.

8. Skerman, V. B. D., V. McGowan, and P. H. A. Sneath. 1980. Approved lists of bacterial names. Int. J. Syst. Bacteriol. 30:225-420.

9. Smith, M. S., M. K. Firestone, and J. M. Tiedje. 1978. The acetylene inhibition method for short-term measurement of soil denitrification and its evolution using nitrogen-13. Soil Sci. Soc. Am. J. 42:611-615.

10. Sneath, P. H. A. 1956. Cultural and biochemical characteristics of the genus Chromobacterium. J. Gen. Microbiol. 15:70-98
11. Sneath, P. H. A. 1960. A study of the bacterial genus Chromobacterium. Iowa State J. Sci. 34:243-500.

12. Sneath, P. H. A. 1974. The genus Chromobacterium, p. 354-357. In R. E. Buchanan and N. E. Gibbons (ed.), Bergey's manual of determinative bacteriology, 8th ed. The Williams \& Wilkins Co., Baltimore.

13. Snell, J. J. S., and S. P. Lapage. 1976. Transfer of some saccharolytic Moraxella species to Kingella Henriksen and Bøvre 1976, with descriptions of Kingella indologenes sp. nov. and Kingella denitrificans sp. nov. Int. J. Syst. Bacteriol. 26:451-458.

14. Van Gent-Ruijters, M. L. W., W. De Vries, and A. H. Stouthamer. 1975. Influence of nitrate on fermentation pattern, molar growth yields and synthesis of cytochrome $b$ in Propionibacterium pentosaceum. J. Gen. Microbiol. 88:36-48.

15. Yoshinari, T., and R. Knowles. 1976. Acetylene inhibition of nitrous oxide reduction by denitrifying bacteria. Biochem. Biophys. Res. Commun. 69:705-710. 